\title{
The Bornean orangutan (Pongo pygmaeus wurmbii) density in a logging concession of Hulu Belantikan, Central Kalimantan, Indonesia
}

\author{
IMAN SAPARI ${ }^{1, \bullet}$, DYAH PERWITASARI-FARAJALLAH ${ }^{2, \bullet v}$, SRI SUCI UTAMI ATMOKO ${ }^{3}$ \\ ${ }^{1}$ Department of Biology, Faculty of Mathematics and Natural Sciences, Institut Pertanian Bogor. Jl. Raya Dramaga, Bogor 16680, West Java, Indonesia. \\ Tel.: +62 251 8625481, Fax.: +62 2518625708 , `email: imansapari_bogor@yahoo.com, \\ ${ }^{2}$ Primate Research Center \& Department of Biology, Faculty of Mathematics and Natural Sciences, Institut Pertanian Bogor. Jl. Raya Dramaga, Bogor \\ 16680, West Java, Indonesia. "»email: wita@pps.ipb.ac.id \\ ${ }^{3}$ Primate Research Center \& Faculty of Biology, Universitas Nasional. J1. Sawomanila, South Jakarta 12520, Jakarta, Indonesia.
}

Manuscript received: 20 June 2018. Revision accepted: 27 February 2019.

\begin{abstract}
Sapari I, Perwitasari-Farajallah D, Utami Atmoko SS. 2019. The Bornean orangutan (Pongo pygmaeus wurmbii) density in a logging concession of Hulu Belantikan, Central Kalimantan, Indonesia. Biodiversitas 20: 878-883. The Bornean orangutan is currently categorized as a critically endangered species. It is found in natural forests in Borneo, where about $78 \%$ of the total population is found outside protected areas, of which $29 \%$ is in logging concessions. This study aimed to analyze the density of the orangutan population and the abundance of fruiting plants in a logging concession and Protection Forest (Hutan Lindung) in the Hulu Belantikan forests in Lamandau District, Central Kalimantan, Indonesia. Research and data collection was conducted between December 2013 to October 2014. Orangutan population density was calculated using line transect methodology based on nest counts. Abundance of fruit plants was calculated using the fruit trail method. The highest orangutan density, 4.8 individuals $/ \mathrm{km}^{2}$, was found in Protection Forest; and the lowest density, 0.4 individuals $/ \mathrm{km}^{2}$, was in [Sopanan] the 2013 logging block. Observations in the logging area indicated that selective logging could alter the structure and gap of the canopy and reduce the proportion of large trees. Changes in forest structure resulted in negative effects on the density of the orangutan population. The remaining degraded forests can still be a valuable resource for the orangutan. As long as the disturbance is not intensive, orangutans will retain access to the less disturbed forest nearby and to forests that are still connected to primary forests. The existence of Protection Forest and old logged-over forests around logging blocks are very important for conservation, providing refugia for orangutans and other species when logging occurs.
\end{abstract}

Keywords: Abundance of fruit plants, Bornean orangutan, population, production forest, protection forest, selective logging

\section{INTRODUCTION}

Orangutans are currently found only on the island of Sumatra (Pongo abelii and Pongo tapanuliensis, Nater et al. 2017) and the island of Borneo (Pongo pygmaeus). Based on The IUCN Red List 2017, all three species of orangutans are categorized as Critically Endangered (CR). The Bornean Orangutan (P. pygmaeus) is divided into three sub-species, namely: $P$. p. pygmaeus, $P$. p. wurmbii and $P$. p. morio (Groves 2001). Of the three sub-species, $P$. $p$. wurmbii has the largest population. Its distribution extends southwards from the Kapuas River in West Kalimantan to Central Kalimantan, and eastwards to the Barito River in South Kalimantan (Groves 2001; Utami-Atmoko et al. 2017).

The primary habitat of Bornean orangutans is peat swamp forest and lowland forest at an altitude of 200-400 meters above sea level (van Schaik et al. 1995; Wich et al. 2008). In addition, Bornean orangutans are commonly found in several habitat types, such as floodplains and peat swamps, alluvial forests along rivers, highlands of foothills and montane forests, selectively logged forests and secondary forest (Meijaard et al. 2006; Ancrenaz et al. 2010).

Seventy-eight percent of the Bornean orangutan population was found outside protected areas, $29 \%$ of which was in the natural forest within logging concessions designated for timber exploitation (Wich et al. 2012). The total population of Borneo orangutans including Sabah and
Sarawak is estimated to be 57,350 individuals, of which 38,200 individuals are the sub-species of P.p.wurmbii (Utami-Atmoko et al. 2017). One of the factors that affect the population size estimate is the value used for orangutan density in a region. The density and movement of orangutans is influenced by the availability of fruit (Buij et al. 2002). Logging of orangutan habitats leads to a decrease in habitat quality by reduction of food plants such as Ficus spp. and lianas (Leighton and Leighton 1983). Factors affecting habitat loss include logging, forest fires, encroachment and conversion for plantations and human settlements (Rijksen and Meijaard 1999).

Hulu Belantikan is the only lowland forest block in Lamandau District, Central Kalimantan, with a status of Limited Production Forest (HPT). The Belantikan landscape extends from the Arut-Belantikan area to Bukit Rangga and Bukit Perai in West Kalimantan Province. Arut and Belantikan are known to have the largest population of $P$. p. wurmbii outside conservation areas, totaling some 6000 individuals in a habitat area of $5100 \mathrm{~km}^{2}$ (Suhartono et al. 2007; Wich et al. 2008). This makes the region an important habitat for orangutan conservation (UtamiAtmoko et al. 2017). Until now, timber extraction by selective logging and iron ore mining are still being carried out in the Belantikan area. Research on the impact of logging on orangutan populations has generally observed in forests after twenty years post-logging (Ancrenaz 2004). 
This study aimed to determine the density of the orangutan population and fruiting plants abundance in three logging blocks (2009-2010, 2012-2013, 2013-2014) and protection forests (ex-logged in the 1970s) in Hulu Belantikan. The results of this study are expected to provide inputs for consideration in designing and implementing orangutan conservation programmes in production forest areas in Hulu Belantikan.

\section{MATERIALS AND METHODS}

\section{Time and location}

The research was conducted from December 2013 to October 2014, in the Limited Production Forest area (HPT) in Hulu Belantikan, which is located in Belantikan Raya,
Lamandau District, Central Kalimantan, Indonesia. The study area is part of the Schwaner mountain range, with an altitude of $25-500 \mathrm{~m}$ asl and a topographic slope of about $15-25 \%$, although the land contours are predominantly undulating and contain many hilly areas. The vegetation type was lowland tropical rainforest dominated by the Family Dipterocarpaceae (Yayorin 2005). Observation transects were made in the Protection Forest (Hutan Lindung; formerly Production Forest, which had been logged-over in the 1970's) and in three falling blocks of the adjoining concession area of PT. Karda Traders (PHPL/sustainable logging certification received in 2009). These blocks were logged during the following periods: 2009-2010; 2012-2013; and 2013-2014 (Table 1).

Table 1. Biophysical conditions, level and types of disturbances in study area

\begin{tabular}{cllll}
\hline \multicolumn{1}{c}{ Location } & $\begin{array}{c}\text { Elevation } \\
\text { m asl }\end{array}$ & \multicolumn{1}{c}{ Contour } & $\begin{array}{c}\text { Level of human } \\
\text { presence } *\end{array}$ & \multicolumn{1}{c}{ Type of disturbance } \\
\hline Protected Forest & $120-340$ & Hilly & Very rare & Seeking durian fruit and hunting animals \\
2009-2010 Block & $90-150$ & Gentle + hilly & Rare & Cultivation and hunting animals \\
2012-2013 Block & $100-210$ & Hilly & Rare & Hunting animals \\
2013-2014 Block & $80-120$ & Gentle slopes & Intensive & Harvesting timber, cultivation and hunting animals \\
\hline
\end{tabular}

Note: *Presence level: 1. Very rare, 1-2 per month; 2. Rare, 3-4 times per month; 3. Intensive, $\geq 5$ times per month
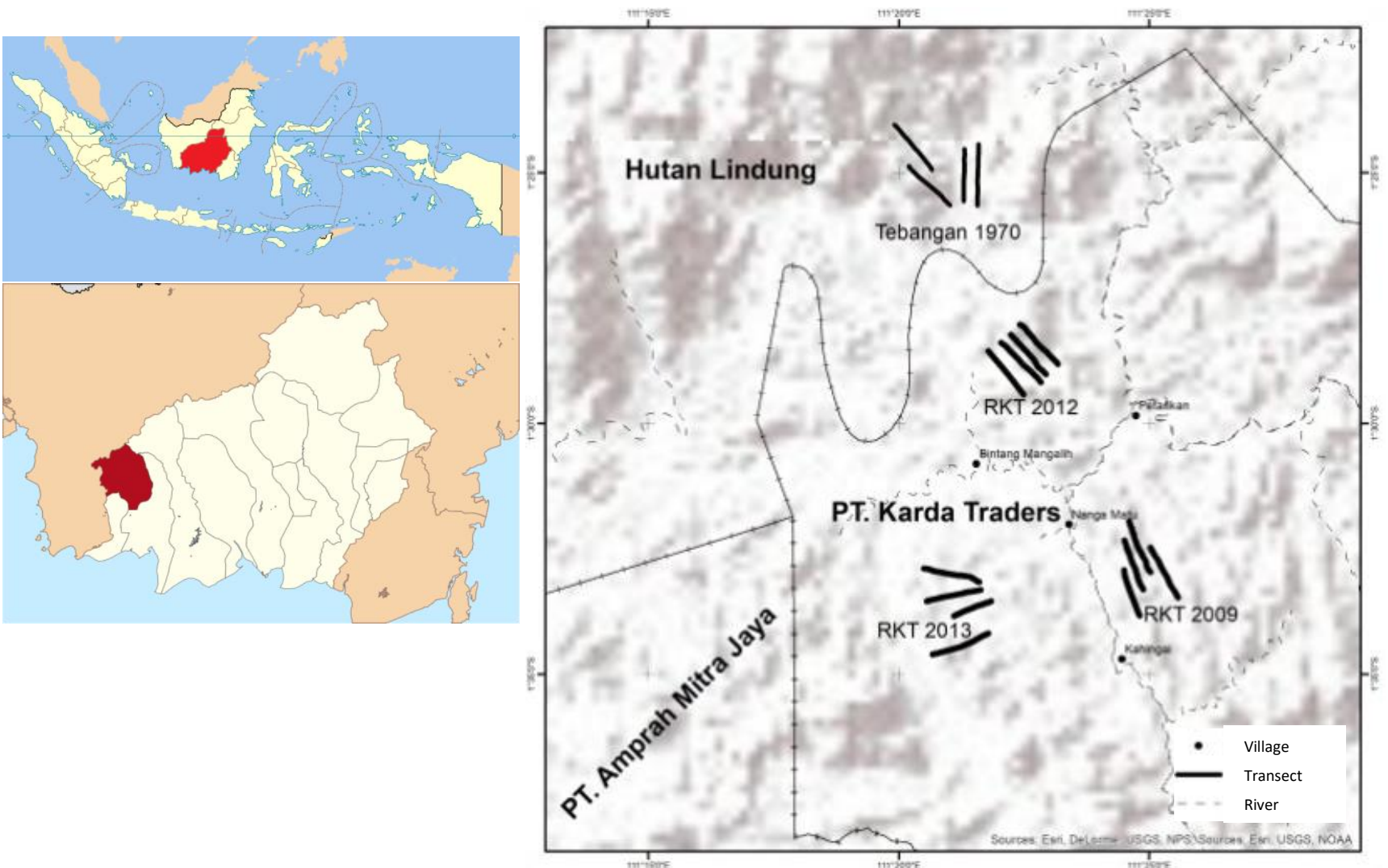

Figure 1. Map of transects in Protection Forest and logging blocks in Belantikan Raya, Lamandau District, Central Kalimantan, Indonesia (Yayorin 2014) 
The presence of humans and the type of disturbance may change according to changes in the logging activities conducted each year. At the time of logging, the access road is open. This will facilitate and encourage the community in Hulu Belantikan to open up fields for cultivation and hunt animals. Community activities always follow the movement of logging activities. The area of community cultivation in and around the logging company road is the research area of block 2012-2014 was 94 ha (Yayorin 2014).

\section{Equipment and materials}

The equipment used during the research included: maps of transect area, cameras, binoculars, distance meters, $\mathrm{dBH}$ meter, Global Position System (GPS), and machetes. This study focused on the recording of orangutan nests and fruiting plant species found in the survey transects.

\section{Orangutan density}

Orangutan density was estimated by the line transect method, based on nest counts (van Schaik et al. 1995). In each location, four transect lines were made each with a length of one $\mathrm{km}$ and distance between transects of 500 meters. The nest parameters recorded were: perpendicular distance of the nest to the line (PPD), nest class or nest age (A, B, C and D), and nest coordinate (Van Schaik et al. 1995). Nest classification was distinguished at nest age, i.e.: (i) Class A, new nest means leaf, still fresh/green or newly abandoned by the owner. (ii) Class B, Nest is still visible tightly, leaves are still intact but not fresh, color changes have begun to occur in the leaves, especially the top of the nest. (iii) Class $\mathrm{C}$, leaves and twigs in the nest have changed color, nest position affects the speed of change, generally, the color of the leaves will be darker brown and at the bottom begins to have holes/leaks and begin to find falling nest leaves. (iv) Class D, Looked twigs and only a few leaves.

In addition, the presence and activities of humans were recorded in each cutting block. Human presence was grouped into levels: (i) Very rare, 1-2 times per month; (ii) Rare, 3-4 times per month; (iii) Intensive, $\geq 5$ per month (Table 1).

\section{Availability of fruiting plants}

To assess the quality of orangutan habitats, a survey of the availability of fruiting plants was carried out using the fruit trail method (van Schaik et al. 1995; Buij et al. 2002). This method is done by observing fresh fruit on the forest floor which indicates that there are plants that are bearing fruit in the area. Using this method yields data on the abundance of fruiting plants per $\mathrm{km}$ along the survey transects. Parameters recorded included: species of fruiting plant, ripeness of the fruit (ripe, half-ripe, or unripe) and fruit type (fleshy/juicy or nut/hard).

Identification of species of fruit trees and orangutan food plants by a taxonomic botanist (Ambriansyah) from Tropenbos-Wanariset Samboja Lestari, Samarinda, Indonesia. Classification was based on the type of flowers, fruits and seeds, morphological characters of trees, and other characters such as the color and aroma of the trunk, sap and bark, and presence of thorns or other accessories.

\section{Data analysis \\ Nest density}

The density of the nests is the number of nests per unit area. Density of nests and individual orangutans were calculated using the formula: $\mathbf{d}=\mathbf{n} / \mathbf{2} \mathbf{w L}$, where $d=$ nest density (nests $/ \mathrm{km}^{2}$ ), $\mathrm{n}=$ the number of nests in the transect, $\mathrm{w}=$ the estimated transect width $(\mathrm{km})$, and $\mathrm{L}=$ length of transects $(\mathrm{km})$. The effective strip width (ESW) of the transect was calculated using DISTANCE 6.1 software (van Schaik et al. 1995).

\section{Density of orangutans}

The density of orangutans is the number of individual orangutans per unit area. Orangutan density based on van Schaik et al. (1995) can be expressed as: D = d / (pxrxt), where $\mathrm{D}=$ orangutan density (individuals $/ \mathrm{km}^{2}$ ), $\mathrm{d}=$ orangutan nest density (nests $/ \mathrm{km}^{2}$ ), $\mathrm{p}=$ the proportion of orangutans in the population that build nests, $r=$ average number of nests individual orangutans made in one day, $t=$ number of days for nests to decay. These values ( $p, r$ and $t$ )refer to values calculated for Gunung Palung National Park (GPNP) in West Kalimantan because we estimated, it is a similar habitat and is close to the study site. Result from GPNP research, yielded values for the proportion of nest builders (p) of 0.89 , average number of nests built (r) of 1.16 nests/individual/day, and for the nest survival visibility value (t) of 259 days (Johnson et al. 2004). A Kruskal Wallis test was carried out to assess the difference in the distribution of nest age or nest class (A, B, C and D) at each location. To compare the population density of orangutans in each survey location (logging blocks 20092010, 2012-2013 and 2013-2014; and Protection Forest) an ANOVA test was conducted. This statistical analysis used SPSS software (Statistic Programming for Scientific and Social Science) version 23.

\section{Abundance of fruiting plants}

The abundance of fruiting plants was estimated as the number of fruiting plants found along the survey transects divided by the length of the survey transects, yielding the unit value of plants $/ \mathrm{km}$. Calculation formula of abundance is expressed as follows:

$$
\text { Abundance of fruiting plants }=\frac{\text { Total fruiting plants recorded }}{\text { Length of survey transect }(\mathrm{km})}
$$

The correlation between the abundance of fruiting plants per transect and orangutan density was analyzed by the Pearson correlation test. This statistical analysis used SPSS software (Statistic Programming for Scientific and Social Science) version 23. 


\section{RESULTS AND DISCUSSION}

\section{Orangutan density}

Based on the ANOVA test result of orangutan densities showed, there was no significant difference $(\mathrm{P}>0,05)$ in density between the 2009-2010 and 2012-2013 logging blocks and the Protection Forest that at each of the four study locations whilst the density in the 2013-2014 logging block was significantly different $(\mathrm{P}<0.05)$. The results of this analysis show that in general, the three logging blocks can support orangutans; except that the 2013-2014 logging block demonstrates the effect of ongoing logging on orangutans.

Orangutans were distributed in all observed habitat conditions (Table 2). The largest number of nests was found in the Protection Forest $(\mathrm{n}=98)$ and the lowest number of nests were found in the 2013-2014 logging block $(n=25)$. This corresponds with the calculated orangutan density, which was highest in the Protection Forest at $4.8 \mathrm{ind} / \mathrm{km}^{2}$ and lowest in the 2013-2014 logging block at $0.4 \mathrm{ind} / \mathrm{km}^{2}$.

The result of a Kruskal Wallis test on orangutan nest classes showed no significant difference in the distribution of orangutan nest classes between locations, i.e., between any of the logging blocks or Protection Forest $(\mathrm{P}>0,05)$. [In general, the ages of nests (A, B, C and D) encountered at each location was found to be evenly distributed.] The effects of logging activities can be seen from the nest classes. Generally, the percentage of new nests in classes A and $\mathrm{B}$ are less than older nests in classes $\mathrm{C}$ and $\mathrm{D}$, especially in areas currently experiencing on-going logging (i.e., the 2013-2014 logging block). The estimation of the total orangutan population based on the counting nests method is affected by nest age or nest class, feed availability, ranging behavior and habitat conditions.

The results showed a significant effect of ongoing logging or timber harvesting activities on the orangutan density. The orangutan densities in the ongoing 2013-2014 logging block were significantly less than those in the Protection Forest and the previous 2012-2013 logging block.

The density orangutans in the Protected Forest (4.8 ind $/ \mathrm{km}^{2}$ ) was higher than other study blocks as the protected forest had recovered since the last period of logging in the 1970's, which caused this forest to have conditions like primary forest and also lower levels of human activity on this protected forest. This condition of protected forest was able to provide more food and protection for orangutans. The lowest orangutan density was found in the 2013-2014 logging block $\left(0.4 \mathrm{ind} / \mathrm{km}^{2}\right)$, because this area was subject to ongoing logging and timber transportation and high human activities (cultivation, illegal logging, and hunting of wildlife, by both local and non-local people). Such high human activity caused orangutans to move away seeking for safer locations in the forest.

Orangutan habitat is determined by the productivity of plants that produce food at the right time and safe resting places (Rijksen and Meijard 1999). Lower density of orangutan in logging areas indicates that selective logging can alter the forest structure, canopy gaps and reduce the proportion of large trees (Johns 1997). Such changes in forest structure can cause negative effects on population density (Felton et al. 2003).

The orangutan density in the 2012-2013 logging block (4.2 ind $/ \mathrm{km}^{2}$ ) was higher than that in 2009-2010 logging block $\left(2.6 \mathrm{ind} / \mathrm{km}^{2}\right)$, even though habitat conditions in the 2009-2010 block were better due to its more advanced restoration condition through natural forest regeneration, because the 2012-2013 logging block was located near both the Protection Forest and old logged-over forest blocks $( \pm 5$ years). This situation allowed orangutans in block 20122013 to move or take refuge in the adjacent Protection Forest when disturbance was high and intensive. When the disturbance had ended, the orangutans could return. These results showed the importance of the connectivity among of protected forests and logging blocks reinforce the results of previous research in Sumatra. Logging sites whose forests are still connected to primary forests are an important prerequisite for the restoration of orangutan densities in logged-over areas (Knop et al. 2004). As long as the disturbance is not intensive, orangutans can maintain access to nearby undisturbed forests, especially for orangutan females that are philopatric (stay on birthplace or home area) (van Noordwijk et al. 2012).

\section{Abundance of fruiting plants}

Orangutans are fruit eaters or frugivores. The abundance of fruit or the presence of fruit sources will attract orangutans to come looking for food. Nevertheless, a Pearson correlation test showed no association $(\mathrm{P}>0.05)$ between orangutan density and abundance of fruit plants in each study location. These results relate to the conditions found in the study locations whereby the abundance of certain fruiting plants is almost evenly distributed in the study area. Although selective logging and timber extraction were underway in the 2013-2014 logging block, fruiting plants were still encountered here from liana types, one of which was Salacia sp. (kirian), an orangutan food (Table 3).

Table 2. Orangutan densities in each survey block

\begin{tabular}{|c|c|c|c|c|c|c|c|c|}
\hline \multirow{2}{*}{ Location } & \multirow{2}{*}{$\begin{array}{l}\text { Total } \\
\text { nests }\end{array}$} & \multirow{2}{*}{$\begin{array}{c}\text { Transect } \\
\text { length }(\mathbf{k m})\end{array}$} & \multirow{2}{*}{$\begin{array}{c}\text { ESWa }^{\mathbf{a}} \\
(\mathbf{m})\end{array}$} & \multicolumn{4}{|c|}{ Nest class $(\mathbf{N})$} & \multirow{2}{*}{$\begin{array}{c}\text { Orangutan } \\
\text { density (ind } / \mathrm{km}^{2} \text { ) }\end{array}$} \\
\hline & & & & $\mathbf{A}$ & $\mathbf{B}$ & $\mathbf{C}$ & D & \\
\hline Protection Forest (logged-over 1970) & 98 & 4 & 9.6 & 0 & 8 & 77 & 13 & 4.8 \\
\hline 2009-2010 Logging Block & 59 & 4 & 10.8 & 2 & 2 & 31 & 23 & 2.6 \\
\hline 2012-2013 Logging Block & 85 & 4 & 9.6 & 2 & 8 & 65 & 10 & 4.2 \\
\hline 2013-2014 Logging Block & 25 & 4 & 28.6 & 3 & 0 & 14 & 8 & 0.4 \\
\hline
\end{tabular}

Note: ${ }^{a}$ ESW : effective strip width 
Table 3. Abundance of fruiting plants in survey blocks

\begin{tabular}{|c|c|c|c|c|c|c|c|}
\hline \multirow[t]{2}{*}{ Location } & \multirow{2}{*}{$\begin{array}{l}\text { Total fruiting plants } \\
\text { (n) }\end{array}$} & \multirow{2}{*}{$\begin{array}{c}\text { Transect } \\
\text { length }(\mathbf{k m})\end{array}$} & \multirow{2}{*}{$\begin{array}{c}\text { Abundance fruiting } \\
\text { plants (ind/km) }\end{array}$} & \multicolumn{2}{|c|}{$\begin{array}{c}\text { Food type } \\
(\%)\end{array}$} & \multicolumn{2}{|c|}{$\begin{array}{c}\text { Fruit type }^{\mathrm{s}} \\
(\%)\end{array}$} \\
\hline & & & & Non-food & Food & $\mathbf{F}$ & $\mathbf{N}$ \\
\hline Protection Forest & 58 & 4 & 15 & 45 & 55 & 72 & 28 \\
\hline $2009-2010$ & 76 & 4 & 19 & 18 & 82 & 70 & 30 \\
\hline 2012-2013 & 54 & 4 & 14 & 39 & 61 & 68 & 32 \\
\hline 2013-2014 & 75 & 4 & 19 & 29 & 71 & 85 & 15 \\
\hline
\end{tabular}

Note: ${ }^{a}$ fleshy/juicy (F) and nut/hard (N)

Table 4. Abundance of fruiting plant species (fruits $/ \mathrm{km}$ ) in each survey block

\begin{tabular}{|c|c|c|c|c|}
\hline Species & $\mathbf{P F}^{*}$ & 2009-2010 & 2012-2013 & 2013-2014 \\
\hline Baccaurea lanceolata (Miq.) Müll.Arg. & 0.75 & & & \\
\hline Democarpus spp. & & 1.5 & & \\
\hline Dillenia reticulata King & 1.0 & & & \\
\hline Durio dulcis Becc. & & & 0.75 & \\
\hline Salacia sp & 0.75 & 2.25 & 0.75 & 6.75 \\
\hline Santiria spp. & & & & 0.5 \\
\hline Syzygium sp. & & & 1.25 & \\
\hline Xantophyllum sp. & & 1.5 & & \\
\hline Xerospermum laevigatum Radlk. & & & & 1.75 \\
\hline
\end{tabular}

Note: ${ }^{*}(\mathrm{PF}=$ Protection Forest $)$

The highest abundance of fruiting plants was found in two different logging blocks, i.e., blocks 2009-2010 and 2013-2014 (Table 3). Logging block 2009-2010 had the highest number of fruiting plants for orangutan, at eightytwo percent, and these were dominated by fruit trees. The results of survey showed that forest regeneration after five years post-logging had begun to provide divers orangutan food. Habitats that constitute good quality for orangutans are those that have trees and lianas that can provide a diet of 30-50\% fruits (Rijksen and Meijard 1999).

In the 2013-2014 logging block, fruit abundance remained high. The fruit species found at this site was, dominated by a fruit species Salacia sp. (kirian) (Table 4). This species is easily found in newly opened areas such as logged-over areas or in community-owned fields. If changes do occur in their habitat, orangutans are dependent on the diversity of liana species (Delgado and van Schaik 2000; Saputra et al. 2017). Dominance of liana fruits indicates that lianas can be an important source of food for orangutans in disturbed forests. This is similar with findings from Sabah that indicate orangutans can adapt in forests that have been lightly logged or subject to sustainable commercial logging (Ancrenaz et al. 2010).

At the Ketambe Research Station in Sumatra, the fleshy juicy fruit (type F) was the main type of fruit chosen by orangutans as a food source $(70 \%)$ compared to other types (Djojosudharmo and van Schaik 1992). In the Limited Production Forest area in Belantikan, the forest one year after logging in logging block 2013-2014 still provided a sufficient abundance of fruits of liana species of type $\mathrm{F}$ ( 0.4 ind $\left./ \mathrm{km}^{2}\right)$. The availability of these fruits can still be used by resident orangutans, especially philopatric females (van Noordwijk et al. 2012).

\section{ACKNOWLEDGEMENTS}

Thanks to Biology Faculty of Universitas Nasional, Jakarta, Indonesia (Dr. Tatang Mitra Setia), Rutgers University (Erin Vogel, Ph.D.), USAID-partnership program, Yayasan Orangutan Indonesia, Orangutan Foundation UK (Ashley Leiman and Yarrow Robertson), BKSDA Central Kalimantan, District Government of Lamandau in Central Kalimantan, Village Chiefs of Bintang Mengalih and Nanga Matu, and Biology Department of Fakultas MIPA, especially the Bio Sains Hewan study program of Bogor Agricultural University (IPB) for the support and assistance provided in this research. Thank also to Ambriyansah, Junadi, Toberto, Bune and all field assistants and Orangutan Research Team in Belantikan (Galuh and Ahmad) for the great assistance in the field.

\section{REFERENCES}

Ancrenaz M, Ambu L, Sunjoto I, Ahmad E, Manokaran K, Meijaard E, Isabelle LA. 2010. Recent surveys in the Forests of Ulu Segama Malua, Sabah Malaysia: show that orangutans (P.p.morio) can be maintained in slightly logged forests. PLoS ONE 5(7): e11510. DOI: 10.1371/journal.pone.0011510.

Ancrenaz M, Calague R, Isabelle LA. 2004. Orangutan nesting behavior in disturbed forest of Sabah Malaysia: Implications for nest census. Intl J Primatol 25 (5): 983-1000.

Buij R, Wich SA, Lubis AH, Sterck EHM. 2002. Seasonal movement in the sumatran orangutan (Pongo abelii) and consequences for conservation. Biol Conserv. 107 (1): 83-87.

Delgado RA, van Schaik CP. 2000. The behavioral ecology and conservation of the orangutan (Pongo pygmaeus): A tale of two islands. Evol Anthrop. 9: 201-219. 
Djojosudharmo S, van Schaik CP. 1992. Why are orangutans so rare in the highlands? Altitudinal changes in a Sumatran forest. Trop Biodivers. 1: 11-22.

Felton AM, Engstrom LM, Felton A, Knott CD. 2003. Orangutan population density, forest structure and fruit availability in hand logged and unlogged peat swamp forests in West Kalimantan, Indonesia. Biol Conserv. 114: 91-101.

Groves CP. 2001. Primate taxonomy. Washington (US): Smithsonian Institution Pr.

Johns GAD. 1997. Timber Product and Biodiversity Conservation in Tropical Rain Forest. Cambridge (UK): Cambridge University Pr.

Johnson AE, Knott CD, Pamungkas B, Pasaribu M, Marshall AJ. 2004. A survey of orangutan (Pongo pygmaeus wurmbii) population in and around Gunung Palung National Park West Kalimantan Indonesia. Biol Conserv. 121: 495-507.

Jones DB, Eudey AA, Geissmann T, Groves CP, Melnick DJ, Morales JC, Shekelle M, Stewart CB. 2004. Asian primate classification. Int J Primatol. 25 (1): 97-164.

Knop E, Ward PI, Wich SA. 2004. A comparison of orangutan density in a logged and unlogged forest on Sumatera. Biol Conserv. 120: 1871192

Leighton M, Leighton D. 1983. Vertebrate Responses to Fruiting Seasonality within a Bornean Rain Forest. In: Sutton SL, Whitmore TC, Chadwick AC, editor. Tropical Rain Forest: Ecology and Management. Boston (US): Blackwell Scientific Publications. pp.181-196.

Meijaard E, Rijksen HD, Kartikasari SN. 2001. Di Ambang Kepunahan Kondisi Orangutan Lliar di Awal Abad ke 21. The Gibbon Foundation, Jakarta.

Meijaard E, Sheil D, Nasi R, Augeri D, Rosenbaum B, Iskandar D, Setyawati T, Lammertink M, Rachmatika I, Wong A, et al. 2006. Hutan pasca pemanenan: Melindungi satwa liar dalam kegiatan hutan produksi di Kalimantan. Bogor (ID): CIFOR.

Nater A, Greminger MPM, Nurcahyo A, Nowak MG, Manuel Md, Desai T, Groves C, Pybus M, Sonay TB, Roos C, et al. 2017 Morphometric, behavioral, and genomic evidence for a new orangutan species. Cur Biol. 27: 1-12.
Rijksen HD, Meijaard E. 1999. Our vanishing relative: The status of wild orang-utans at the close of the twentieth century. Tropenbos Publication, Nederland.

Saputra F, Perwitasari-Farajallah D, Utami-Atmoko SS, Ariyanto T, Van Noordwijk MA. 2017. Monthly range of adolescent orangutan (Pongo pygmaeus wurmbii) based on fruit availability in Tuanan Orangutan Research Station, Central Kalimantan, Indonesia. Biodiversitas. 18: 1445-1452.

Utami-Atmoko SS, Traylor-Hozler K, Rifqi MA, Siregar P, Achmad B, Priadjati A, Husson S, Wich SA, Hadisiswoyo P, Saputra F, et al. 2016. The Orangutan Population and Habitat Viability Assessment of 2017. The Directorate General of Natural Resources and Ecosystem Conservation, Ministry of Environment and Forestry of Indonesia, Bogor.

van Noordwijk MA, Arora N, Willems EP, Dunkel LP, Amda RN, Mardianah N, Ackermann C, Krutzen M, van Schaik CP. 2012. Female philopatry and its social benefits among Bornean orangutans. Behav Ecol Sociobiol. 66: 823-834.

Van Schaik CP, Azwar, Priatna D. 1995. Population estimates and habitat preferences of orangutans based on line transects of nests. In: Nadler RD, Galdikas BMF, Sheeran LK, Rosen N (eds.). The Neglected Ape. Plenum, New York

Wich SA, Gaveau D, Abram N, Ancrenaz M, Baccini A, Brend S, Currant L, Delgado RA, Erman A, Fredriksson GM. 2012. Understanding the impacts of land use policies on a threatened species: is there a future for Bornean orangutan?. PLoS ONE 7(11): e49142. DOI: 10.1371/journal.pone.0049142.

Wich SA, Meijaard E, Marshall AJ, Husson S, Ancrenaz M, Lacy RC, Van Schaik CP, Sugardjito J, Simorangkir T, Traylor-Holzer, K, et al. 2004. Distribution and conservation status of the orangutan (Pongo spp.) on Borneo and Sumatera: How many remain. Oryx. 42 (3): 329339.

Yayorin. 2005. Keanekaragaman Hayati \& Sosial Ekonomi Budaya Masyarakat Tiga Desa, Hulu, Kalimantan Tengah. Yayorin, Pangkalan Bun. [Indonesia] 